\title{
Variasi Genetik Itik Bayang Berbasis Marka Mikrosatelit Pada Lokus AY287 dan Lokus AY283
}

\author{
Rusfidra $^{1)}$, Y. Heryandi ${ }^{1)}$, Jamsari $^{2)}$, dan E. Y. Rahman ${ }^{3)}$ \\ ${ }^{1)}$ Program Studi Peternakan, Fakultas Peternakan Universitas Andalas, Padang \\ ${ }^{2)}$ Laboratorium Bioteknologi Fakultas Pertanian Universitas Andalas, Padang \\ ${ }^{3)}$ Program Pascasarjana Universitas Andalas, Padang \\ Email: rusfidra@gmail.com
}

\begin{abstract}
ABSTRAK
Provinsi Sumatera Barat memiliki sumber daya genetik ternak itik yang potensial sebagai penghasil daging dan telur, salah satunya itik Bayang. Itik Bayang merupakan plasma nutfah ternak yang pada tahun 2012 ditetapkan Kementerian Pertanian sebagai rumpun ternak nasional. Marka mikrosatelit banyak digunakan sebagai penciri genetik karena keberadaannya berlimpah, bersifat kodominan dan polimorfik. Tujuan penelitian ini adalah untuk mengetahui variasi genetik itik Bayang berdasarkan marka mikrosatelit lokus AY287 dan AY283. Material DNA yang digunakan adalah sampel darah dari 24 ekor itik Bayang di Kabupaten Pesisir Selatan. Hasil isolasi DNA dari 24 sampel darah itik Bayang dapat dideteksi oleh gel elektroforesis. Hasil penelitian menunjukkan bahwa lokus AY287 menghasilkan 6 alel yakni alel A (108 bp), alel B (142 bp), alel C (183 bp), alel D (227 bp), alel E (272 bp) dan alel F (340 bp). Alel E dan alel F merupakan alel spesifik dan dapat digunakan sebagai penciri khusus itik Bayang. Frekuensi alel itik Bayang pada lokus AY287 adalah alel C $(26,93 \%)$, alel D (19,24\%), alel A (15,38\%), alel B (15,38\%), alel E $(15,38 \%)$ dan alel F $(7,69 \%)$. Lokus AY283 menampilkan 6 alel, yakni alel A (230 bp), alel B (320 bp), alel C (345 bp), alel D (390 bp), alel E (450 bp) dan alel F (500 bp). Frekuensi alel berturut-turut adalah alel B (20,51\%), alel D $(20,51 \%)$, alel E $(20,51 \%)$, alel A $(15,39 \%)$, alel C $(15,39 \%)$, dan alel F $(7,69 \%)$. Hasil amplifikasi menunjukkan bahwa jumlah alel pada lokus AY287 dan AY283 bersifat polimorfik pada itik Bayang.
\end{abstract}

Kata kunci: itik Bayang, mikrosatelite, AY287, AY283

Genetic Variation of Bayang Duck Based on Microsatelite Marker on AY287 and AY283 Loci

\begin{abstract}
West Sumatera Province has poultry genetic resource of local duck that potential in supply eggs and duck meat. Bayang duck was set by Indonesian Agricultural Ministry in 2012 as national livestock breeds in Indonesia. Microsatellite markers are widely used as a genetic identifier because of their abundant existence, co-dominant and high polymorphic. The purpose of this study was to determine the genetic diversity of Bayang ducks based on two microsatellite loci which include AY287 and AY283. DNA substances used in the study were blood samples from 24 Bayang duck in Pesisir Selatan Regency. The isolated DNA genom from 24 blood samples of Bayang duck could be detected by gel electrophoresis. Results showed that AY287 locus has 6 alleles; allele A (108 bp), allele B (142 bp), allele C (183 bp), allele D (227 bp), allele E (272 bp) and allele $F(340 \mathrm{bp})$. Both allele $E$ and $F$ were specific genetic markers of Bayang duck. Alleles frequencies of the AY287 locus were as follow: allele $C(26,93 \%)$, allele $D(19,24 \%)$, allele $A(15,38 \%)$, allele $B(15,38 \%)$, allele $E(15,38 \%)$ and allele $F(7,69 \%)$. The AY283 locus has 6 alleles consisted of allele A (230 bp), allele B (320 bp), allele $C$ (345 bp), allele D (390 bp), allele $E(450 \mathrm{bp})$ and allele $F(500 \mathrm{bp}$ ). Allele frequencies of this marker were allele $B(20,51 \%)$, allele $D(20,51 \%)$, allele $E(20,51 \%)$, allele $A(15,39 \%)$, allele $C(15,39 \%)$, and allele $F(7,69 \%)$, respectively. Our finding suggest that two microsatellite markers, AY287 and AY283, were polymorphic in Bayang duck population.
\end{abstract}

Key words: Bayang duck, microsatellite, AY283, AY287 


\section{PENDAHULUAN}

Itik Bayang merupakan plasma nutfah ternak itik di Provinsi Sumatera Barat yang pada tahun 2012 ditetapkan Kementerian Pertanian sebagai rumpun ternak nasional. Rusfidra dan Heryandi (2010); Rusfidra et. al. (2012); Kusnadi dan Rahim (2009) menyatakan bahwa itik Bayang merupakan itik Lokal yang dipelihara petani di Kabupaten Pesisir Selatan dan sangat potensial dikembangkan sebagai penghasil daging dan telur.

Keragaman genetik sangat diperlukan dalam upaya pemuliaan ternak, karena dengan diketahuinya keragaman genetik ternak dimungkinkan untuk membentuk bangsa ternak baru melalui seleksi dan sistem perkawinan (TixierBoichard et.al. 2009). Ismoyowanti dan Purwantini (2010) menyatakan bahwa identifikasi dan karakterisasi populasi itik lokal sangat penting dilakukan untuk identifikasi plasma nutfah dan pengembangan program pemuliaan.

Sampai kini karakterisasi marka molekuler itik Bayang belum banyak dilakukan. Salah satu pendekatan yang dapat dilakukan adalah mengetahui keragaman genetik itik Bayang berbasis marka mikrosatelit. DNA bukan gen yang berulang secara berurutan disebut mikrosatelit. Mikrosatelit atau Short Tandem Repeats (STRs) merupakan untaian basa nukleotida 1 - 6 pasang basa yang berulang dan tersebar di dalam genom (Clementino et.al. 2010).

Mikrosatelit merupakan penanda genetik yang banyak digunakan untuk mempelajari pautan (linkage), pemetaan, analisis populasi, sistem perkawinan dan struktur populasi (Silva et. al., 1999). Mikrosatelit banyak digunakan sebagai penciri genetik karena keberadaannya berlimpah, bersifat kodominan dan kemungkinan polimorfik tinggi (Bennet, 2000). Mikrosatelit juga dapat digunakan dalam keperluan identifikasi individu, keanekaragaman dan struktur populasi, atau mempelajari evolusi dari spesies yang berkerabat (Clisson et al., 2000). Ciampolini et al. (1995) menyatakan bahwa DNA mikrosatelit banyak digunakan sebagai penanda molekuler untuk mendukung aktifitas pemuliaan ternak seperti kegiatan identifikasi ternak, penetapan asal-usul keturunan dan penggalian sumber-sumber genetik.

Variasi alel mikrosatelit dapat dihitung melalui pemisahan produk PCR secara elektroforesis. Dengan mengidentifikasi pita yang muncul setelah elektroforesis (satu pita untuk homozigot dan dua pita untuk heterozigot) maka genotip suatu individu dapat ditentukan dan frekuensi alel dalam suatu populasi dapat dihitung (Muladno, 2000). Beberapa studi menunjukkan sekuen berulang DNA (mikrosatelit) dapat digunakan untuk mengidentifikasi asal usul individu dari suatu populasi (Edwards et. al., 2000).

Tujuan penelitian ini adalah untuk mengidentifikasi variasi genetik itik Bayang berdasarkan marka mikrosatelit lokus AY283 dan AY287. Hasil penelitian ini dapat digunakan sebagai dasar program pemuliaan itik Bayang di Sumatera Barat dengan menggunakan penciri DNA mikrosatelit sebagai marker assisted selection.

\section{MATERI DAN METODE}

\section{Populasi Ternak dan Pengambilan Sampel Darah}

Material DNA yang digunakan untuk marka mikrosatelit adalah sampel darah 12 ekor itik Bayang yang dipelihara peternak di Kecamatan Bayang dan 12 ekor itik Bayang di Kecamatan Lengayang, Kabupaten Pesisir Selatan, Sumatera Barat. Darah diambil dengan mengunakan jarum suntik $0,5 \mathrm{ml}$. Sampel darah diambil melalui vena akselaris pada bagian sayap sebanyak $0,3 \mathrm{ml}$, kemudiaan dimasukkan ke dalam tabung venojeck dan dikocok membentuk angka 8 dan disimpan dalam lemari es untuk mencegah pembekuan darah. 
Tabel 1. Primer yang digunakan dalam penelitian molekuler itik Bayang.

\begin{tabular}{clccc}
\hline Lokus & \multicolumn{1}{c}{ Sekuen primer } & $\begin{array}{c}\text { Suhu } \\
\text { Annealing } \\
\left({ }^{\circ} \mathrm{C}\right)\end{array}$ & $\begin{array}{c}\text { Ukuran } \\
\text { Alel (bp) }\end{array}$ & Sumber \\
\hline AY283 & $\begin{array}{l}\text { GACCACAACATCGTGCAGAG } \\
\text { GATAATGGCTGGCTCCTTGA }\end{array}$ & 50,9 & $211-371$ & Su et. al (2007) \\
\hline AY287 & $\begin{array}{l}\text { TGCAGGTAGGTCTTCTGTTCTG } \\
\text { GCCAGTCCTTTGCTTCGTAA }\end{array}$ & 60,8 & $154-295$ & Su et. al (2007) \\
\hline
\end{tabular}

\section{Isolasi dan Purifikasi DNA}

Isolasi DNA dilakukan mengunakan metoda Sambrook et. al., (1989) dengan modifikasi dengan mengunakan purifikasi DNA kit produksi Promega. Isolasi DNA diawali dengan pengambilan $100 \mu \mathrm{l}$ sampel darah di campur dengan $300 \mu$ l larutan sel lysis dan $8 \mu \mathrm{l}$ proteinase $\mathrm{K}$ dalam tabung sentrifus steril ukuran $1,5 \mathrm{ml}$, dengan cara membolak-balik tabung sebanyak 5-6 kali. Larutan yang telah tercampur diinkubasi pada suhu $65^{\circ} \mathrm{C}$ selama 1 jam. Kemudian lakukan sentrifus dengan kecepatan 15.000 rpm selama 1 menit. Selanjutnya supernatan dibuang dan peletnya ditinggalkan. Proses isolasi diulangi 4 sebanyak 3 kali. Pelet yang tersisa divortex sampai larut. Kemudiaan tambahkan $300 \mu \mathrm{l}$ larutan nuclei lysis, kemudian dipipet cairan up-down sampai larutan bersifat viscous. Kemudian tambahkan protein precipitation sebanyak $200 \mu \mathrm{l}$ dan akan terbentuk endapan yang berwarna keruh. Selanjutnya larutan tersebut disentrifus dengan kecepatan $15.000 \mathrm{rpm}$ selama 3 menit, sehingga terbentuk dua bagian, yakni pellet dan supernatan. Supernatan diambil dan ditransfer ke dalam tabung sentrifus baru yang steril (ukuran 1,5 $\mathrm{ml})$ dan ditambah dengan isopropanol sebanyak $300 \mu 1$.

Supernatan yang telah dicampur tersebut disentrifus dengan kecepatan 15.000 rpm selama 1 menit. Supernatant dibuang dan pellet dicuci dengan etanol $70 \%$ dingin sebanyak $500 \mu \mathrm{l}$. Pellet disentrifus dengan keepatan $10.000 \mathrm{rpm}$ selama 5 menit. Etanol lalu dibuang dengan pipet, kemudiaan tabung dibalik dan dikeringkan di atas tisu pada suhu ruang selama 10-15 menit. Pellet yang telah dikeringkan ditambah dengan larutan DNA re-hydrasi $50-100 \mu$, kemudian tabung di-typing hingga pellet menjadi larut. Hasil isolasi tersebut diuji dengan menggunakan elektroforesis dengan campuran $4 \mu \mathrm{l}$ 1xTE, $1 \mu \mathrm{l}$ BPB, $2 \mu \mathrm{l}$ DNA dan $2 \mu \mathrm{l} \lambda$ - DNA ladder dengan menggunakan $1 \%$ agarose pada tegangan 100 volt selama 60 menit.

\section{Amplifikasi DNA Mikrosatelit dengan Polymerase Chain Reaction (PCR)}

Reaksi PCR dilakukan menurut metode Sambrook et.al. (1989). Komposisi larutan untuk runing PCR terdiri dari Go Taq Green $12,5 \mu \mathrm{l}+7,5 \mu \mathrm{l} \mathrm{ddH}_{2} \mathrm{O}+3 \mu \mathrm{l}$ DNA sampel $+2 \mu \mathrm{l}$ primer F dan R. Primer yang digunakan dalam penelitian ini menggunakan primer yang yang telah dilaporkan Su et.al. (2007) (Tabel 1). Suhu annealing disesuaikan dengan suhu annealing masing-masing primer, yakni primer AY287 $\left(60,8{ }^{\circ} \mathrm{C}\right)$ dan primer AY283 $\left(50,9{ }^{0} \mathrm{C}\right)$. Proses amplifikasi DNA berlangsung selama 2 jam 20 menit. DNA hasil amplifikasi lalu dielektroforesis bersama $1 \mathrm{~kb}$ DNA ladder dengan menggunakan $1,5 \%$ agarose pada tegangan 100 Volt selama 90 menit. Hasil elektroforesis diamati dengan $U V$ transiluminator. Pola pita DNA dipotret dengan unit gel dokumentasi.

\section{Penentuan Posisi Pita DNA Mikrosatelit}

Jika terdapat dua pita maka sampel tersebut bersifat heterozigot dan jika terdapat satu pita maka bersifat homozigot. Untuk memudahkan skoring pita yang paling 
bawah diberi sandi A dan selanjutnya B, C, dan seterusnya sampai pita paling atas. Semua pita yang memiliki laju sama merupakan alel yang homolog (Nei, 1987).

\section{Analisis Data}

\section{Frekuensi Alel}

Frekuensi alel lokus AY287 dan AY283 dihitung menurut Nei dan Kumar (2000):

Keterangan :

$$
x_{i}=\left(2 n_{i j}+\Sigma n_{i j}\right) /(2 N)
$$

$\mathrm{j} \quad \neq 1$

$\mathrm{x}_{\mathrm{i}}=$ frekuensi alel ke-i

$\mathrm{n}_{\mathrm{ij}}=$ jumlah individu untuk genotip $_{\mathrm{ij}}$

$\mathrm{N}=$ jumlah sampel

\section{Frekuensi Genotipe}

Frekuensi Genotipe ditentukan dengan cara membagi jumlah sampel itik Bayang yang memiliki genotipe tertentu dengan seluruh jumlah itik Bayang yang diamati dan dihitung menurut Nei dan Kumar (2000):

Keterangan :

$$
\mathbf{x}_{\mathbf{i}}=\boldsymbol{\Sigma} \mathbf{n}_{\mathbf{i}} / \mathbf{N}
$$

$\mathrm{x}_{\mathrm{i}}=$ frekuensi genotipe ke- $\mathrm{i}$

$\mathrm{n}_{\mathrm{i}}=$ jumlah individu bergenotipe $\mathrm{i}$

$\mathrm{N}=$ jumlah individu sampel

\section{HASIL DAN PEMBAHASAN}

\section{Isolasi DNA Genom dan Reaksi PCR}

Amplifikasi DNA mikrosatelit pada itik Bayang dianalisis dengan menggunakan dua lokus, yaitu: AY287 dan AY283 (Su et. al., 2007). Amplifikasi PCR pada kedua lokus dapat mengamplifikasi 24 sampel itik Bayang. Penggunaan kedua lokus tersebut karena memiliki keragaman yang tinggi. Alel ditentukan oleh variasi pita DNA yang muncul pada gel agarose. Alel merupakan sekuen DNA yang berbeda pada lokus yang sama. Perbedaan yang muncul dianggap sebagai alel berbeda. Pola elektroforesis lokus AY287 dan AY283 dapat dilihat pada Gambar 1 dan 2.

\section{Lokus AY287}

Hasil penelitian menunjukkan bahwa lokus AY287 menampilkan 6 alel, yakni alel A (108 bp), alel B (142 bp), alel C (183 bp), alel D (227 bp), alel E (272 bp) dan alel F (340 bp). Ukuran alel berkisar dari 108 $340 \mathrm{bp}$. Jumlah alel yang diperoleh pada itik Bayang lebih rendah dari itik China dengan jumlah 15 alel dengan ukuran alel 154-294 bp (Su et al., 2007). Ismoyowati dan Purwantini (2010) melaporkan bahwa variasi genetik pada dua bangsa itik Lokal Indonesia, yaitu itik Alabio dan Bali adalah bersifat polimorfik dengan jumlah alel 2-3 dan ukuran alel 100-500 bp. Sementara itu studi variasi genetik pada itik Tegal, Magelang dan Bali berbasis mikrosatelit pada lokus ADL-115, ADL-209, ADL-231, ADH-23, ADH-24 dan ADH-09 dilaporkan oleh Ismoyowati dan Purwanti (2011) bersifat polimorfik, dengan jumlah alel 5-7 dengan ukuran alel 80-760 bp.

Variasi dari 6 alel yang dihasilkan pada lokus AY287 menunjukkan bahwa alel E dan alel $F$ diduga merupakan alel spesifik yang hanya ditemui pada itik Bayang yang berasal dari Kecamatan Bayang dan tidak ditemukan pada itik Bayang di Kecamatan Lengayang. Alel $\mathrm{E}$ dan alel $\mathrm{F}$ dapat digunakan sebagai penciri khas itik Bayang di Kecamatan Bayang. Jumlah dan ukuran alel pada lokus AY287 dapat dilihat pada Gambar 1.

Frekuensi alel itik Bayang pada lokus AY287 berturut-turut adalah alel C $(26,93 \%)$, alel D $(19,24 \%)$, alel A $(15,38 \%)$, alel B (15,38\%), alel E $(15,38 \%)$ dan alel F $(7,69 \%)$. Frekuensi alel dan genotype dapat dilihat pada Tabel 2 .

\section{Lokus AY283}

Hasil penelitian menunjukkan bahwa lokus AY283 menampilkan 6 alel, yakni alel A (230 bp), alel B (320 bp), alel C (345 bp), alel D (390 bp), alel E (450 bp) dan alel F (500 bp). Ukuran alel adalah $230-500 \mathrm{bp}$. Jumlah alel yang diperoleh pada penelitian ini lebih kecil dibandingkan jumlah alel pada itik China yang dilaporkan Su et al., (2007) 
Tabel 2. Jenis dan ukuran alel pada itik Bayang

\begin{tabular}{|c|c|c|c|c|c|c|}
\hline Lokus & $\begin{array}{c}\text { Jumlah } \\
\text { Alel }\end{array}$ & $\begin{array}{c}\text { Populasi } \\
\text { Sampel }\end{array}$ & Genotip & $\begin{array}{c}\text { Frekuensi } \\
\text { Genotip (\%) }\end{array}$ & $\begin{array}{l}\text { Alel dan Ukuran } \\
\text { (bp) }\end{array}$ & $\begin{array}{c}\text { Frekuensi } \\
\text { Alel (\%) }\end{array}$ \\
\hline AY287 & 6 & 24 & $\begin{array}{l}\text { AA (2) } \\
\text { BC (2) } \\
\text { BD (1) } \\
\text { CC (7) } \\
\text { DD (2) } \\
\text { EE (2) } \\
\text { EF (2) } \\
\text { ABC (1) } \\
\text { ACD (1) } \\
\text { BCD (2) } \\
\text { CEF (2) }\end{array}$ & $\begin{array}{c}8,33 \\
8,33 \\
4,17 \\
29,17 \\
8,33 \\
8,33 \\
8,33 \\
4,17 \\
4,17 \\
8,33 \\
8,33\end{array}$ & $\begin{array}{l}\text { A (108) } \\
\text { B (142) } \\
\text { C (183) } \\
\text { D (227) } \\
\text { E (272) } \\
\text { F (340) }\end{array}$ & $\begin{array}{c}15,38 \\
15,38 \\
26,93 \\
19,24 \\
15,38 \\
7,69\end{array}$ \\
\hline AY283 & 6 & 24 & $\begin{array}{l}\text { CD (3) } \\
\text { DE (1) } \\
\text { ACD (1) } \\
\text { AB (2) } \\
\text { EE (1) } \\
\text { DE (1) } \\
\text { BB (1) } \\
\text { BF (1) } \\
\text { BE (1) } \\
\text { EF (1) } \\
\text { AC (1) } \\
\text { BC (5) } \\
\text { AA (1) } \\
\text { AD (1) } \\
\text { BCD (1) } \\
\text { CDE (1) } \\
\text { BDEF (1) }\end{array}$ & $\begin{array}{c}12,5 \\
4,17 \\
4,17 \\
8,33 \\
4,17 \\
12.5 \\
8,33 \\
4,17 \\
4,17 \\
4,17 \\
4,17 \\
4,17 \\
4,17 \\
20,83 \\
4,17 \\
4,17 \\
4,17\end{array}$ & $\begin{array}{l}\text { A (230) } \\
\text { B (320) } \\
\text { C }(345) \\
\text { D }(390) \\
\text { E }(450) \\
\text { F }(500)\end{array}$ & $\begin{array}{c}15,39 \\
20,51 \\
15,39 \\
20,51 \\
20,51 \\
7,69\end{array}$ \\
\hline
\end{tabular}

Tabel 3. Derajat Heterozigositas itik Bayang

\begin{tabular}{lc}
\hline \hline Lokus & Derajat Heterozygositas $(\hat{\mathrm{h}})$ \\
\hline AY287 & 0,591 \\
AY283 & 0,750 \\
\hline Rataan Heterozygositas $(\hat{\mathrm{H}})$ & 0,671 \\
\hline
\end{tabular}

pada lokus AY283 sebesar 17 alel dengan ukuran alel 211 - $371 \mathrm{bp}$.

Frekuensi alel berturut-turut adalah alel B (20,51\%), alel D (20,51\%), alel E $(20,51 \%)$, alel A $(15,39 \%)$, alel C $(15,39 \%)$, dan alel F (7,69\%). Lokus AY283 bersifat polimorfik sebesar $87,5 \%$ dan monomorfik sebesar 12,5\%. Lokus AY283 tidak memiliki alel spesifik sebagai penciri khas itik Bayang dari dua Kecamatan yang berbeda di Kabupaten Pesisir Selatan.

\section{Derajat Heterozigositas}

Nilai heterozigositas lokus AY283 ( $\hat{\mathrm{h}}=$ $0,750)$ lebih tinggi dari nilai heterozigositas lokus AY287 ( $\hat{\mathrm{h}}=0,591)$. Nei (1987) menyatakan bahwa nilai heterozigositas $(\hat{\mathrm{h}})$ merupakan indikator paling akurat untuk mengukur variasi genetik. Derajat heterozigositas dapat diperoleh dari rataan persentase lokus heterozigot tiap individu atau rataan persentase individu heterozigot di dalam populasi (Nei dan Kumar, 2000). 


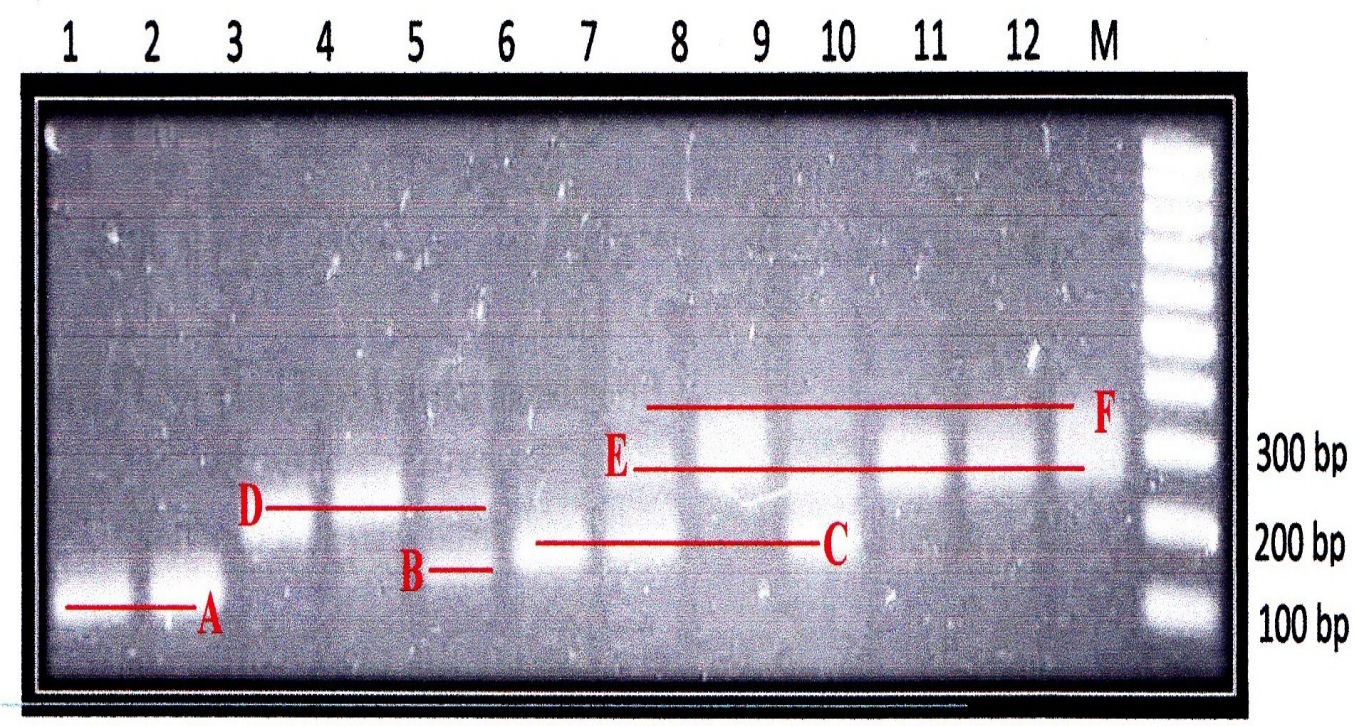

\section{AA AA DD DD $\quad B D \quad C C$ CEF EF CEF EE EE EF}

Gambar 1. Pola pita lokus AY287

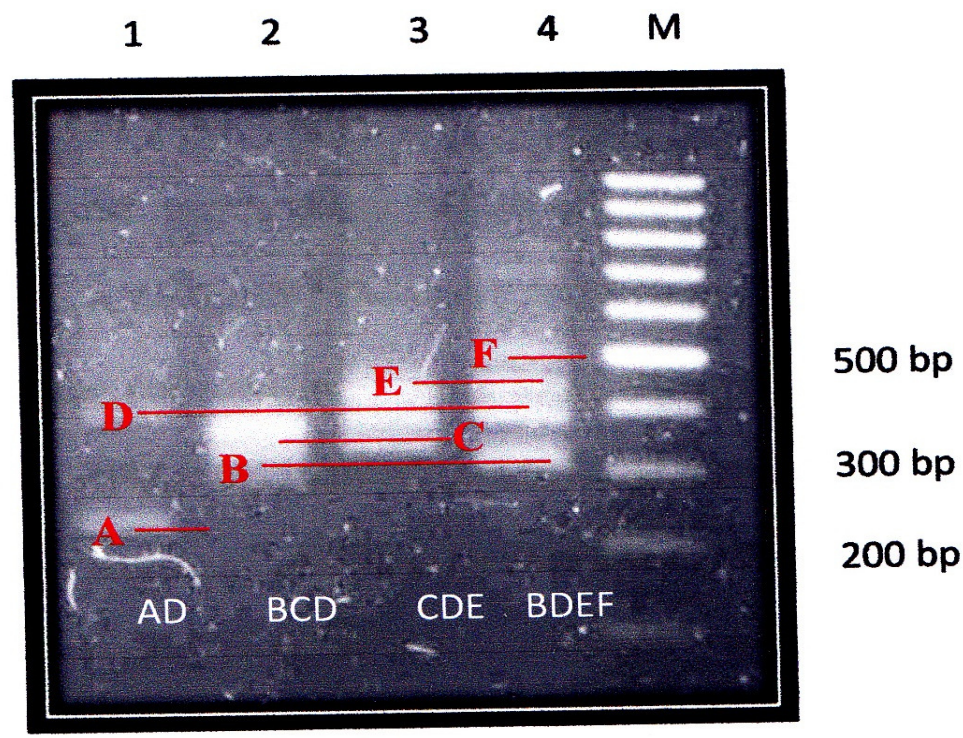

Gambar 2. Pola pita lokus AY283

Nilai rataan heterozigositas pada penelitian ini yaitu rataan heterozigositas berdasarkan lokus yang berbeda. Rataan heterozigositas dipengaruhi oleh ukuran populasi dan jumlah lokus yang dianalisis dan untuk menduga rataan heterozigositas pada suatu lokus minimal membutuhkan 2030 sampel (Nei, 1987). Derajat heterozigositas itik pada Lokus AY287 dan AY283 dapat dilihat pada Tabel 3.
Nilai rataan heterozigositas lokus adalah sebesar 0,671 . Rendahnya nilai rataan heterozigositas pada penelitian ini diduga disebabkan karena jumlah lokus yang digunakan hanya 2 lokus yaitu AY287 dan AY283 serta jumlah sampel yang terbatas $(n=24$ ekor). Nei dan Kumar (2000) menyatakan bahwa nilai heterozigositas ditentukan oleh jumlah sampel, jumlah dan nilai frekuensi alel. 


\section{SIMPULAN DAN SARAN}

Marka molekuler itik Bayang pada lokus AY287 dan AY283 bersifat polimorfik. Lokus AY287 menampilkan 6 alel, yakni alel A (108 bp), alel B (142 bp), alel C (183 bp), alel D (227 bp), alel E (272 bp) dan alel F (340 bp). Lokus AY283 menampilkan 6 alel, yakni alel A (230 bp), alel B (320 bp), alel C (345 bp), alel D (390 bp), alel E (450 bp) dan alel F (500 bp).

Perlu dilakukan penelitian lanjutan untuk menentukan keragaman itik Bayang dengan jumlah sampel dan lokus yang lebih banyak, sehingga hasil yang diperoleh akan lebih akurat. Selain itu, identifikasi keragaman itik Bayang dapat dilakukan dengan penciri DNA lainnya seperti teknik PCR-RFLP dan PCR-SSCP.

\section{UCAPAN TERIMAKASIH}

Ucapan terimakasih disampaikan kepada DP2M Ditjen Pendidikan Tinggi atas bantuan biaya penelitian dalam Skim Hibah Strategis Nasional pada Tahun 2010 dengan judul penelitian "Inventarisasi, Karakterisasi dan Konservasi Sumber Daya Genetik Itik Lokal Sumatera Barat".

\section{DAFTAR PUSTAKA}

Bennet, P. 2000. Microsatellites. J Clin Pathol. 53:177-183.

Ciampolini, R., K. M. Goudarzi., D. Vaiman., C. Dilman, E. Mazzanti, J.L. Fouley, H. Leveziel and D. Cianci. 1995. Individual multilocus genotypes using microsatellites polymorphism to permit the analysis of the genetic variability within and between Italian beef cattle. $\mathbf{J}$ Anim Sci. 73: 3259-3268.

Clementino, C.S., F.J.V. Barbosa., A.M.F. Calvalo., R.A.R. Costa-Filho., G.R. Silva., E.G. Campelo., F.B. Britto and F.M. Diniz. 2010. Microsatelite DNA loci for population studies in Brazilian chicken ecotypes. International. J Poult Sci. 9 (12): 100-106.

Clisson, I., M. Lathuilliere and B. Croau-Roy. 2000. Conservation and evolution microsatellite loci in primate taxa. Am J Prim. 50: 205-214.

Edwards, C.J., C. Gailard., D. G. Bradley and D. E. Machugh. 2000. Y-spesific microsatellite polymorphism in a range of bovine species. Anim Genet. 31: 127130.

Ismoyowati and D. Purwantini. 2010. An estimation of genetic variation of Indonesian Local duck using microsatellite marker. Asian J Poult Sci. 4 (4): 198-204.

Ismoyowati and D. Purwantini. 2011. Genetic variability of Bali and Alabio duck on the basis of phenotypic and microsatellite. Asian J Poult Sci. 5 (3): 107-115.

Kusnadi, E and F. Rahim. 2009. Effect of floor density and feeding system on the weight of bursa of fabricius and spleen as well as the plasma triiodothyronine level of Bayang duck. Pakistan J Nut. 8 (11): 1743-1746.

Muladno., R. R. Noor and B. Tappa. 2000. The genomic mapping of Bali cattle: Early strategy and an effort to production of "tandemly repeated sequence" and "interspearse repetitive sequence" as DNA marker. Report of Integrated Competitive Research Grand Program VI (1997-1999). National Research Council, Ministry of Research and Technology.

Nei, M. 1987. Molecular Evolutionary Genetics. Columbia University Press. New York.

Nei, M. and S. Kumar. 2000. Molecular Evolutionary and Phylogenetics. Oxford University Press, New York.

Rusfidra, M. H. Abbas dan R. Yalti. 2012. Struktur populasi, ukuran populasi efektif dan laju inbreeding per generasi itik Bayang. Prosiding Seminar Nasional Peternakan Berkelanjutan IV. Bandung: Fakultas Peternakan Universitas Padjajaran. ISBN: 978-602-95808-6-2.

Rusfidra dan Y. Heryandi, 2010. Inventarisasi, karakterisasi dan konservasi sumber daya genetik itik Lokal Sumatera Barat. Laporan Penelitian Hibah Strategis Nasional Tahun 2010.

Sambroook, J., E. Fritsch and T. Maniatis. 1989. Molecular Cloning; Laboratory Manual. $2^{\text {nd }}$ Edition. Cold Spring Harbor Laboratory Press. 
Silva, F., L. Gusmao and A. Amorim. 1999. Segregation analysis of tetra and penta nucleotide short tandem repeat polymorphism: Deviation from mendelian expectation. Electrophoresis, 20: 1697-1701.

Su, Y., R. Long., G. Chen., X. Wu., K. Xie and J. Wan. 2007. Genetic analysis of six endangered local duck population in China based on microsatellite marker. J Genet and Genom. 34(11): 1010-1018

Tixier-Boichard, M, A. Bordas and X. Rognon. 2009. Characterisation and monitoring of poultry genetic resources. World's Poult Sci. 65: 272-285. 